\title{
ESTONIA'S YOUTH LABOUR MARKET: UNEMPLOYMENT AND MIGRATION SENTIMENTS OF STUDENT YOUTH
}

\author{
${ }^{1 *}$ Natalia PROVOTAR, 'Victor PARENYUK, ${ }^{2}$ Mart REIMANN \\ 'Taras Shevchenko National University of Kyiv, Ukraine \\ ${ }^{2}$ Tallinn University, Estonia \\ 1*provotarnat@ukr.net, ${ }^{2}$ mart@tlu.ee
}

\begin{abstract}
This article presents an analysis of current processes in the youth labour market in the context of their impact on the student youth migration sentiments with a focus on the case of Estonia. Nowadays, student migration takes new forms, which are determined by objective and subjective factors and need to be conceptualized. They are characterized by complicated socio-economic interactions and social relations, so the analysis is based not only on statistics but also on the results of a survey of student youth conducted in November-December 2019.

The analysis of the youth labour market in Estonia revealed the relationship between unemployment and education levels and some trends in the unemployment dynamics. This made it possible to identify key processes, such as spread of circular and chain migration, an increasing intensity of migration flow, transition to positive values of net migration. The analysis confirmed that Estonia's accession to the EU had a positive effect on the youth labour market, and the improvement of the socio-economic situation in the country was the main reason for growing migration flow of young people from abroad.

The identification of migration sentiments of student youth is based on the analysis of factors that push them from the country of origin and pull to the countries of possible migration. Countries that are the most attractive forEstonian students in terms of education and employment have been identified, including ones with a positive image for immigration, high wage level and favourable working conditions. It is determined that the migration aspirations of the respondents are quite high. The migratory attitudes of student youth towards permanent migration are analysed in relation to the education of parents and the level of foreign language proficiency.
\end{abstract}

Key words: youth, labour market, unemployment, migration sentiments, survey, Estonia.

DOI: https://doi.org/10.17721/2413-7154/2020.83.12-20

UDC: $911.3: 331.5: 314.7$

Received: May 23, 2020.

Revised: June 3, 2020.

Accepted: June 5, 2020.

\section{МОЛОДІЖНИЙ РИНОК ПРАЦІ ЕСТОНІЇ: БЕЗРОБІТТЯ ТА МІГРАЦІЙНІ НАСТРОЇ СТУДЕНТСЬКОї МОЛОДІ}

\author{
1*Наталія ПРОВОТАР, 'Віктор ПАРЕНЮК, 'Март РЕЙМАНН \\ 'Київський начіональний університет імені Тараса Шевченка, Україна \\ ${ }^{2}$ Талліннський університет, Естонія \\ 1*provotarnat@ukr.net, ${ }^{2}$ mart@tlu.ee
}

Анотація: У статті представлено аналіз сучасних процесів на молодіжному ринку праці в контексті їхнього впливу на міграційні настрої студентської молоді на прикладі Естонії. Нині міграції студентської молоді набувають нових форм, які зумовлюються об'єктивними та суб'єктивними чинниками і потребують концептуалізації. Їх характеризують складні соціально-економічні взаємодії та соціальні відносини, тому для аналізу використано не лише статистичні дані, але i результати опитування студентської молоді, проведені в листопаді-грудні 2019 року.

Аналіз молодіжного ринку праці Естонії дозволив виявити взаємозв'язок між рівнями безробіття та освіти, виділити часові тренди динаміки безробіття. Це дало можливість ідентифікувати ключові процеси, зокрема поширення циркулярної та ланцюгової міграції, зростання інтенсивності міграційного потоку, перехід до позитивного сальдо міграції. Аналіз підтвердив, що входження Естонії до ЄС мало позитивний ефект для ринку праці молоді, а покращення соціально-економічної ситуації в країні стало головною причиною збільшення міграційного притоку молоді з інших країн.

Виявлення міграційних настроїв студентської молоді здійснено на основі визначення факторів її виштовхування з країни проживання та притягання до країн можливої міграції. Ідентифіковано найбільш привабливі для естонських студентів країни в аспекті отримання освіти та працевлаштування, серед яких країни з позитивним іміджем для імміграції, високою оплатою та сприятливими умовами праці. Визначено, що міграційні прагнення респондентів $\epsilon$ достатньо високими. Міграційні настрої студентської молоді щодо постійної міграції проаналізовані у взаємозв'язку із освітою батьків та рівнем володіння іноземною мовою.

Ключові слова: молодь, ринок праці, безробіття, міграційні настрої, опитування, Естонія. 


\section{Постановка проблеми}

У світі наразі домінують процеси глобалізації та економічної інтеграції. При цьому людський капітал стає головним чинником формування і розвитку економіки, підвищує конкурентоспроможність країн на світових ринках товарів та послуг. За таких умов актуалізувались міграції студентської молоді, які набувають різних форм. Вони викликані як об'єктивними, так і суб'єктивними чинниками, що зумовлюють «виштовхування» i «притягування» молодих людей на навчання та на роботу. Для України, як одного 3 постачальників інтелектуального потенціалу в різні країни світу, ця тема $\epsilon$ актуальною в контексті значних масштабів відтоку молоді за кордон та втрати можливості залучити їі до активної соціально-економічної життєдіяльності в Україні. Особливої гостроти ця проблема набуває 3 огляду на демографічну кризу в Україні, з одного боку, та підготовки недостатньої кількості фахівців iз затребуваних на національному ринку праці спеціальностей.

Проблема молодіжного безробіття в Україні та недостатньо вивчених міграційних настроїв молоді потребує порівняльного аналізу ситуації на ринках праці різних країн і, насамперед, країн Європейського Союзу (ЄС). Найбільший дослідницький інтерес становлять країни, які 3 Україною об'єднує минуле - перебування в складі СРСР чи групі соціалістичних країн. Такою країною $є$ Естонія, яка однією 3 перших постсоціалістичних країн пройшла шлях демократичних змін і з 2004 року є повноправним членом ЄС. Україна наразі обрала шлях демократичних перетворень та співпрацю з СС з намірами вступу до цієї організації.

За індексом потенційної міграції, розрахованим Інститутом громадської думки (Інститут Геллапа) Естонія входить до групи європейських країн 3 найбільшими потенційними міграціями молоді 3 показником 35\% (частка молоді, яка б погодилася змінити країну проживання за певної можливості). В Україні цей показник є ще вищим і складає 42\% (American Institute of Public Opinion, 2020).

Нині існує ряд теорій, які пояснюють ті чи інші аспекти міграції та явищ, які її супроводжують. В процесі появи нових чинників та мотивів міграційної поведінки формуються нові концепції міграцій, окремі положення ще перебувають в процесі становлення. Сучасні концепції міграційної поведінки населення пов'язані переважно 3 економічними та соціально-психологічними теоріями. Але роль відстані, простору, регіональних особливостей залишає їх в полі географічного трактування (Niemets $\&$ Mezentsev, 2019, р. 138). Головними питаннями дослідження міграцій є: 3 точки зору соціології соціальне «включення та виключення мігрантів», які втрачають певні соціальні зв'язки чи набувають нові; з точки зору економіки - соціально-економічні чинники, що впливають на прийняття рішення щодо міграції та їх економічні наслідки; 3 точки зору географії - уточнення просторових закономірностей міграції (Brettell \& Hollifield, 2014, p. 4).

В Україні дослідженням проблем безробіття та міграції молоді, що мають міждисциплінарний характер, присвячено велику кількість праць соціологів, економістів та соціо-економіко-географів. Їх висновки зводяться до того, що на ринку праці у найгіршому становищі перебуває молодь (понад $40 \%$ зареєстрованих безробітних складає молодь віком 16-29 років) (Mezentsev et al., 2014, р. 73). В реаліях сьогодення молодіжні ринки праці особливо вразливі до фінансово-економічних спадів і криз, терористичних загроз і геополітичного напруження, а також до неефективного державного управління (внутрішньополітичні суперечності, корупція, бюрократизм). Негативною є тенденція до поширення на молодіжному ринку праці неформальної практики зайнятості в «тіньовому» секторі, зубожіння та маргіналізації працюючих молодих людей (Dubych, 2017, p. 92).

Нині в Україні досить сильними є міграційні тенденції та настрої, особливо серед молоді. Україна $\epsilon$ одним із найбільших донорів та реципієнтів трудових мігрантів (Dubych 2017). Негативними наслідками молодіжного безробіття стали міграція кваліфікованої молоді за кордон на навчання i працевлаштування та пов'язане $з$ цим зниження рівня народжуваності, поширення бідності та соціальних негараздів серед молоді (Mezentsev \& Mezentseva, 2018). Щодо особливостей молодіжної міграції, то відмічається, що молоді українські працівники є більшою мірою сконцентрованими у певних галузях економічної діяльності, що робить їх положення більш вразливим до структурних змін на зарубіжних ринках праці (Maidanik, 2010).

В Естонії дискурс щодо ситуації на молодіжному ринку праці та міграційних настроїв молоді зосереджений на кількох аспектах. Зокрема, відмічається, що високий рівень безробіття молоді, по-перше, є величезним невикористаним ресурсом, який не можна дозволити втратити, а по-друге, зростаючою загрозою соціальної кризи (Paliskova, 2014). Увага акцентується на тому, що після вступу до ЄС еміграція стала вибірковою за рівнем освіти, етнічної приналежності, віку та регіону (Anniste, 2014). При цьому частка населення 3 вищою освітою, що емігрує 3 Естонії, значно нижча, ніж серед населення загалом. Це відрізняє країну від багатьох інших країн, що беруть участь у східно-західній міграції в Свропі, включаючи території колишнього Радянського Союзу (Anniste et al., 2012). Водночас, окрім постійних міграцій та міграцій для сезонних робіт, в Естонії поширеними стали тимчасові та циркулярні міграції. Через легкий доступ до ринків праці інших країн ЄС та відносно дешеві засоби транспорту, мобільність через державні кордони стала способом життя для багатьох європейців, які кілька разів змінюють країни проживання та уникають складання довгострокових планів (Anniste, 2014). Хоча в останні роки спостерігається диверсифікація 
міграції, трансформація паттернів і розмивання границь між різними типами мобільності (GrzymalaKazłowska \& Brzozowska, 2017).

Метою написання даної роботи є аналіз сучасних процесів на молодіжному ринку праці в контексті їхнього впливу на міграційні настрої студентської молоді на прикладі Естонії. Соціо-економікогеографічний підхід передбачає проведення такого дослідження 3 використанням даних офіційної статистики (Statistics Estonia, 2020) та опитування студентської молоді 3 метою виявлення факторів виштовхування 3 країни проживання та факторів притягання країн потенційно можливої міграції, а також визначення привабливих країни в аспекті отримання освіти та працевлаштування студентів, аналізу міграційного потенціалу респондентів.

\section{Виклад основного матеріалу дослідження}

Сучасні тенденції та процеси на молодіжному ринку праці Естоніі

На ринку праці ЄС групою найвищого ризику безробіття є молоді працівники віком 15-24 роки. Рівень безробіття молоді 15-24 років в країнах ЄС впродовж 2005-2018 рр. був вищим за середній показник безробіття і у 2-2,5 рази перевищував рівень безробіття у вікових групах 25-54 роки та 55-64 роки (рис. 1).

Результатом реалізації стратегії економічного розвитку «Європа 2020», що одним із пріоритетів визначає підвищення рівня освіти та рівня зайнятості молоді, стало зниження рівня безробіття молоді iз $23,5 \%$ у 2013 році до $15,2 \%$ - у 2018 році. Проте, всередині ЄС існує велика розбіжність зазначеного показника. Так, у 2018 році найменшим (менше $10 \%$ рівень безробіття молоді був у Чехії, Данії, Німеччині, Нідерландах, Австрії, Словенії, Мальті, а найбільшим - у Греції (39,9\%), Іспанії (34,3\%) та Італії $(32,2 \%)$.
Ринок праці Естонії як невеликої відкритої економіки значною мірою залежить від сусідніх країн та світового ринку, а його жорсткість та зарегульованість були чи не найбільш серйозною проблемою (Eamets, 2013), що значно поглибилась внаслідок фінансової кризи 2007-2009 років та потребувала реформування 3 метою посилення гнучкості та відкритості ринку праці. Дослідники відмічають, що вступ Естонії до Європейського Союзу у 2004 році зумовив значний імпульс пошуку можливостей працевлаштування естонців за кордоном, а вплив фінансової кризи 2007-2009 років ще більше загострив ситуацію на ринку праці країни. Як наслідок, М. Сіппола робить висновок, що не мали бажання чи можливості брати участь у трудових міграціях бідні та літні люди і не громадяни СС, що проживали в Естонії (Sippola, 2014).

Після тривалого зниження рівня безробіття в Естонії протягом 2001-2007 років у кризовий період цей показник суттєво зріс (3 4,1\% у грудні 2007 року до $19,8 \%$ у червні 2010 року) і надалі залишався доволі високим, особливо серед менш освічених працівників. Поряд 3 цим ринок праці Естонії характеризувався більш суворим законодавством щодо захисту зайнятості порівняно 3 іншими центральноєвропейськими країнами та дуже низькими витратами на політику активізації ринку праці (Brixiova \& Egert, 2012).

Бриксьова та Егерт (2012) на основі розробленої моделі вбачали кілька заходів, які б дозволили підвищити гнучкість ринку праці і, таким чином, полегшити відновлення та покращити середньострокові результати, зокрема посилення стимулювання безробітних шукати роботу або брати участь у програмах навчання та пошуку роботи, 3 одного боку, та стимулювання фірм до створення робочих місць, з іншого (Brixiova \& Egert, 2012).

Реформа ринку праці Естонії 2009 року мала два ключові напрями, з одного боку передбачаючи

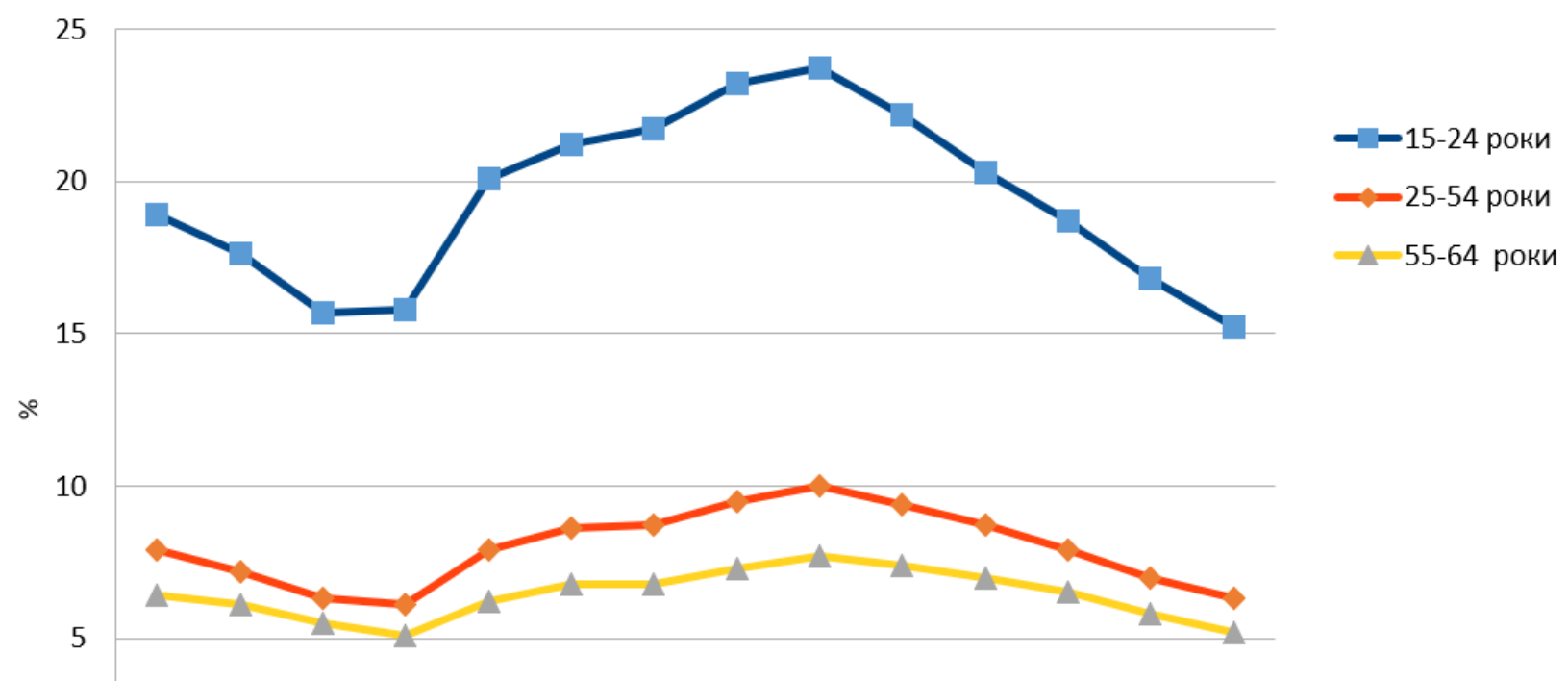

Рис. 1. Динаміка рівня безробіття у різних вікових групах населення в країнах ЄС у 2005-2018 рр. (за даними Statistics Estonia, 2020) 
стимулювання на законодавчому рівні більшої гнучкості у трудових відносинах, а 3 другого - інституційні зміни, пов'язані із об'єднанням Національної ради з ринку праці та Фонду страхування від безробіття в єдину структуру (Eamets, 2013).

На молодіжному ринку праці Естонії впродовж 2000-2018 років можна виділити три періоди з різною динамікою рівня безробіття. Перший період тривав до 2008 року і характеризувався після вступу до ЄС зниженням рівня безробіття молоді, який досяг свого мінімуму у 2007 році (10,1\%). В цей період рівень безробіття молоді був нижчим за середній показник в СС. У період 2008-2011 років, що включав світову фінансову кризу, показник безробіття молоді в Естонії суттєво різко зріс і значно перевищив середні його значення у ЄС. Якщо в середньому в СС у 2010 році рівень безробіття молоді складав $21,2 \%$, то в Естонії - 32,9\% (у Латвії, Литві та Іспанії ситуація була ще гіршою - 36,2\%, 35,7\% та 41,5\% відповідно). Третій період (2012-2018 років) характеризувався поступовим зниженням показника безробіття та нижчим його рівнем в Естонії, ніж у $\mathrm{CC}$ в цілому (рис. 2).

Ринок праці молоді Естонії характеризується вищим рівнем безробіття у чоловіків, порівняно із жінками. Лише у періоди соціально-економічних трансформацій 2001-2003 років та у 2006 і 2013 роках рівень безробіття жінок був вищим. Ще однією суттєвою рисою $є$ те, що у 2009-2010 роках, коли рівень безробіття молоді був найвищим, кількість

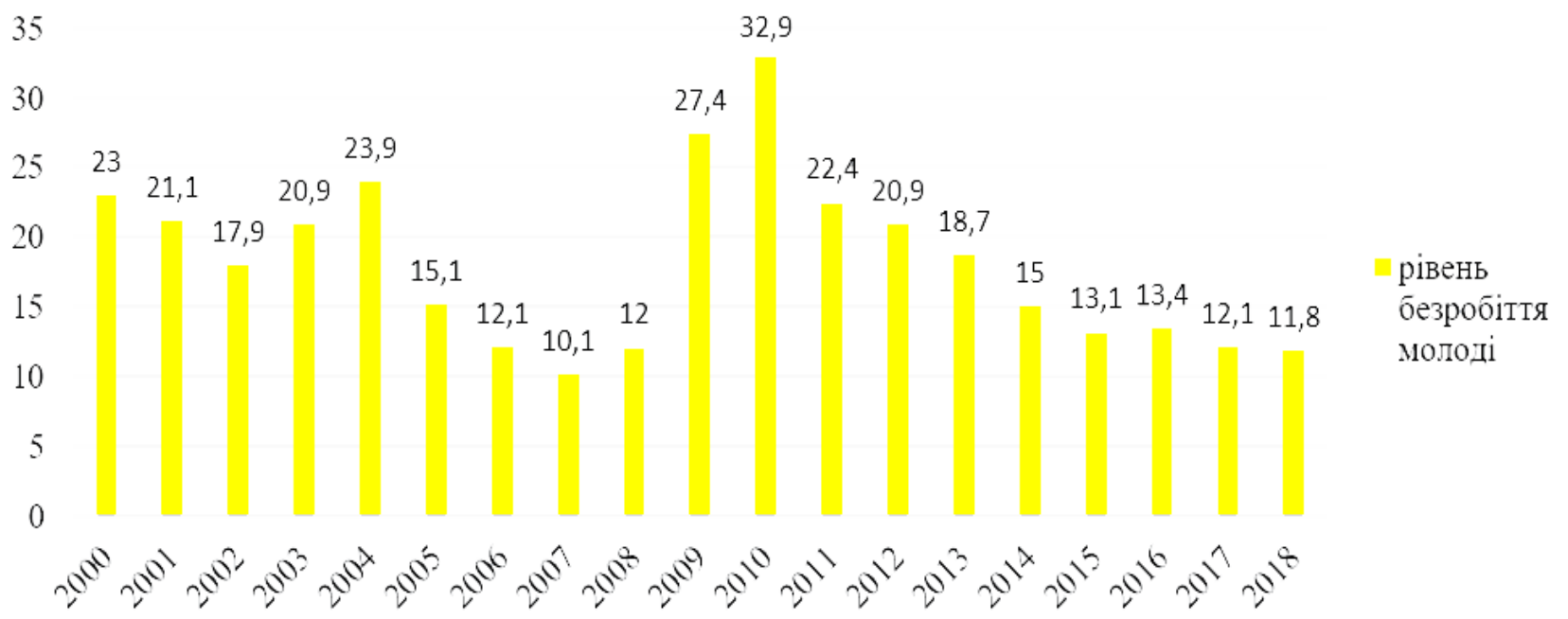

Рис. 2. Динаміка рівня безробіття молоді в Естонії у 2000-2018 рр. (за даними Statistics Estonia, 2020)

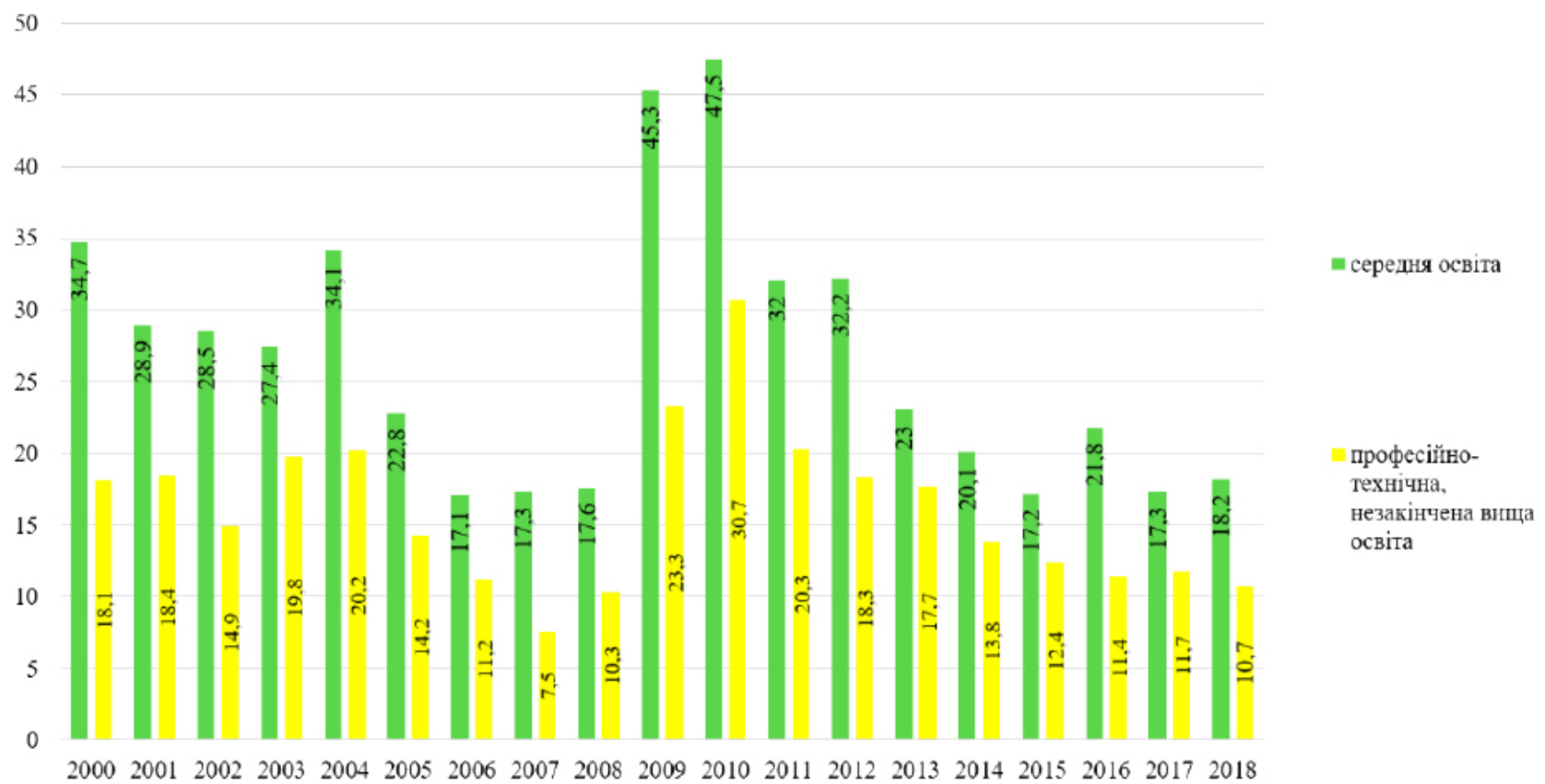

Рис. 3. Динаміка рівня безробіття молоді в Естонії залежно від рівня освіти у 2000-2018 рр.

(за даними Statistics Estonia, 2020) 
безробітних молодих чоловіків була на 10\% вищою, ніж молодих жінок.

Суттєвий вплив на рівень безробіття молоді в Естонії та можливості отримання роботи має професійна освіта та кваліфікація. Впродовж 20002018 років молодь із середньою освітою мала значно вищий рівень безробіття, ніж молодь, що мала професійно-технічну освіту та незакінчену вищу освіту (рис. 3). Найсуттєвішою ця різниця була у 2009 році, коли рівень безробіття молоді із професійнотехнічною та незакінченою вищою освітою був майже вдвічі нижчим, ніж у молоді, що мала лише середню освіту.

Динаміка галузевої структури зайнятості молоді в Естонії свідчить про те, що частка зайнятої молоді у галузях вторинного сектора має тенденцію до скорочення, а у третинному - до зростання. Так, у 2018 році 73,8\% зайнятої молоді працювали у третинному секторі, 22,4\% - у вторинному секторі і лише 3,7\% - у первинному, тоді як у 2000 році це співвідношення було зовсім іншим $-55,7 \%, 39,0 \%$ та 5,3\% відповідно.

Вступ Естонії до ЄС суттєво вплинув на міграції населення і молоді зокрема. Наприклад, еміграція 3 Естонії до Великої Британії та Ірландії, які відкрили свої ринки праці для країн Центральної та Східної Європи без перехідного періоду, з 2000 по 2008 рік збільшилися більш ніж у вісім разів, до Фінляндії більш ніж у п'ять разів.

Відбулися зміни у складі емігрантів. Спочатку зросла частка високоосвічених емігрантів, а частка емігрантів, які не мають вищої освіти, зросла 3 моменту вступу Естонії до ЄС у 2004 році. По-друге, мігранти стали молодшими. По-трете, починаючи з 2004 року зросла кількість мігрантів із сільських поселень Естонії (Anniste, 2014).

Цікавим аспектом $є$ дослідження міграційної поведінки сільської молоді у постсоціалістичній Естонії. Зокрема, Р. Нугін підкреслює, що перехідний характер постсоціалістичного сільського життя та його вразливість, зумовлена демографічною структурою населення, сприяють розумінню молодими людьми життя як постійного потоку, а міграція розглядається як «нормальна частина культури». Тому дослідниця припускає, що, можливо, державна політика повинна однаково підтримувати як прагнення молоді залишатися в сільській місцевості, так і виїжджати, оскільки 3 цим важко боротися (Nugin, 2014).

Оскільки показник тимчасової міграції естонців є одним 3 найвищих в $€ С$, особливу увагу дослідників присвячено вивченню мігрантів, які повертаються. Так, Й. Массо та ін. (Masso et al., 2014) в результаті аналізу впливу зарубіжного досвіду на сферу зайнятості мігрантів, що повертаються, не виявили жодного позитивного впливу на підвищення їхньої професійної мобільності (Masso et al., 2014). Серед молоді, що повертається, переважають чоловіки 3 вищою освітою, зайняті переважно у сфері обслуговування (Tverdostup \& Masso, 2016). Також було виявлено, що серед молодих мігрантів, що повернулися, рівень освіти не впливав на рішення про повернення незалежно від країни міграції, але прослідковується вплив невідповідності рівня освіти та сфери зайнятості серед молодих високоосвічених естонських емігрантів (Masso et al., 2018).

Щодо кількості іммігрантів та емігрантів віком 19-24 роки у Естонії у 2000-2018 роках чітко прослідковуються три періоди. Перший період (2000-2004 роки) до вступу Естонії в ЄС характеризується незначною інтенсивністю міграції молоді та переважанням еміграції над імміграцією. Другий період (2005-2014 років) характеризується зростанням інтенсивності міграцій у 2-3 рази і також переважанням еміграції над імміграцією за виключенням 2009 року, коли імміграція кількісно переважала над еміграцією. Третій період (2015-2018 років) характеризується зростанням інтенсивності

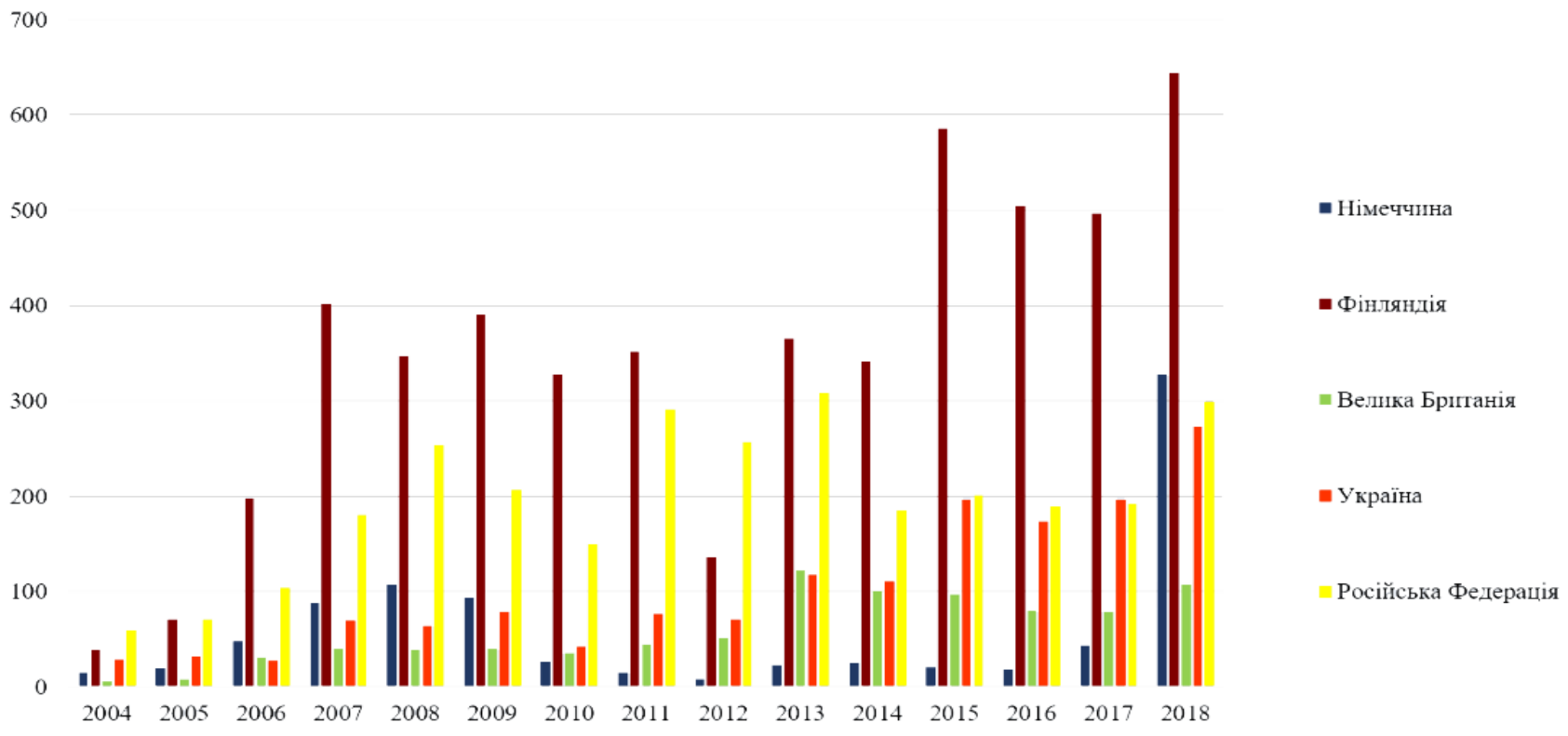

Рис. 4. Імміграція до Естонії молоді віком 15-29 років у 2004-2018 рр. (за даними Statistics Estonia, 2020) 
міграцій порівняно з попереднім у 2-3 рази. При цьому імміграція молоді переважала над еміграцією. Так, у 2018 році чисельність молоді, що іммігрувала в Естонію вдвічі перевищила кількість молоді, що емігрувала.

Найбільше молоді іммігрувало до Естонії 3 Фінляндії та Російської Федерації. Проте чіткої закономірності щодо збільшення чи зменшення кількості іммігрантів не прослідковується (рис. 4), тобто явище є ситуативним. До п’ятірки країн-лідерів за чисельністю іммігрантів молодого віку до Естонії входять Україна, Німеччина та Великобританія. При цьому Україну вирізняє суттєве зростання показника із 5 осіб у 2006 році до 273 осіб у 2018 році.

В Естонії поширеним видом міграцій $\epsilon$ циркулярна. Ті мігранти, які водночас бажають підтримувати тісні контакти 3 Естонією, часто обирають Фінляндію як країну призначення. При цьому більшість з них зберігають соціальні контакти, сімейне життя чи проведення дозвілля у Естонії. Причини такої циркулярної міграції пов'язані 3 наявністю роботи, вищою заробітною платою, високою транспортною доступністю, відсутністю суттєвого мовного бар'єру у Фінляндії. Оскільки циркулярні мігранти вважають свою міграцію тимчасовою i планують незабаром повернутися, вони не ведуть активного суспільного життя у Фінляндії. Але відсутність інтеграції в суспільне життя часто викликає стрес у мігрантів і відчуття самотності. Однак через географічну близькість Естонії та Фінляндії, мігранти, як правило, регулярно відвідують домівки i тому часто відкладають повернення (Anniste, 2014).

Ще одним напрямом досліджень ринку праці та міграції в Естонії є мовне питання. Так, К. Ліндеман виявила, що високий рівень володіння естонською мовою збільшує шанси на успіх на ринку праці для представників етнічних меншин не в першому поколінні (Lindemann, 2014). При цьому, в порівнянні з Україною, знання російської мови відіграє меншу роль на ринку праці Естонії (Lindemann \& Kogan, 2013).

\section{Міграційні настрої студентської молоді}

У листопаді-грудні 2019 року було проведене опитування студентів у Талліннському університеті в Школі Природничих Наук та Здоров'я (School of Natural Sciences and Health) через мережу інтернет за допомогою електронної анкети Google Forms. Метою опитування студентської молоді було дослідити їх потенційну міграційну поведінку та визначити чинники, які впливають на прийняття рішення щодо міграції. Для цього були поставлені такі завдання: проаналізувати обізнаність респондентів стосовно освітніх програм та програм 3 працевлаштування в країні проживання та за кордоном, а також їх участь в таких програмах; виявити фактори виштовхування 3 країни проживання та притягання країн потенційно можливої міграції, а також визначити привабливі країни в аспекті отримання освіти та працевлаштування для студентів; проаналізувати міграційний потенціал респондентів.
Розроблена анкета включала 32 питання за трьома взаємопов'язаними блоками: блок питань стосовно міграційних намірів студентів; блок питань стосовно факторів виштовхування та притягання мігрантів; блок питань стосовно загальних відомостей про респондентів в контексті оцінки міграційного потенціалу.

В опитуванні взяли участь 50 респондентів віком 19-27 років. Серед опитаних 68\% жінок та $32 \%$ чоловіків. $85 \%$ респондентів до вступу в Талліннський університет проживали в містах, 15\% - в сільській місцевості.

1. Обізнаність респондентів стосовно освітніх програм та програм з працевлаштування в краӥні проживання та за кордоном, участь в них.

Важливим критерієм ефективності різних освітніх програм є обізнаність та рівень залучення до них цільової аудиторії. 74\% респондентів відповіли, що знаютьпро регіональні та урядові цільові програми підтримки молоді, однак лише 25\% назвали такі програми. Більшість респондентів вказала програму Erasmus+, а також була названа програма YFU.

В цілому на запитання «чи володієте Ви достатньою інформацією щодо можливостей здобути освіту за кордоном?» 56\% опитаних студентів відповіли «так».

Понад $18 \%$ опитаних брали участь у студентських програмах, які пропонують освіту за кордоном. Дві третини опитаних відповіли, що хотіли б взяти участь у подібних програмах у майбутньому.

Лише $12 \%$ респондентів брали безпосередню участь в студентських програмах, які пропонують роботу за кордоном. При цьому 80\% вказали, що хотіли б взяти участь у таких програмах у майбутньому.

На запитання про джерело інформації про навчання чи роботу за кордоном, якому студенти найбільше довіряють, відповіді розподілились наступним чином: 69,4\% - друзям, 67,3\% - лише офіційній інформації, $61,2 \%$ - родичам, 42,9\% інформації перевіреній особисто (респондентам пропонувались назвати від одного до трьох варіантів). На таку структуру відповідей суттєво вплинуло те, що у 78\% респондентів є родичі/друзі/знайомі, які працюють за кордоном. У $28 \%$ опитаних вони працюють на постійній основі.

Отже, обізнаність респондентів стосовно освітніх програм та програм 3 працевлаштування в країні проживання та за кордоном можна вважати такою, що відповідає середньому рівню. Аргументується це тим, що лише 12 респондентів 350 вказали назви двох таких програм; лише $18 \%$ та $12 \%$ респондентів брали участь в освітніх програмах та програмах 3 працевлаштування, які $є$ дуже популярними серед студентської молоді в ЄС. Тому враховуючи бажання та можливості опитаних $(80,4 \%$ респондентів відповіли, що хочуть брати участь у подібних програмах у майбутньому, 78\% мають родичів, друзів, які працювали або працюють за кордоном), можна стверджувати, що міграційні наміри студентів суттєво пов'язані із навчанням та працевлаштуванням за кордоном у майбутньому. 
2. Фактори виштовхування з краӥни проживання та притягання країн, привабливих в аспекті отримання освіти та працевлаштування для еміграчіï.

Найпривабливішими країнами для здобуття освіти студенти назвали Велику Британію (обрали $34 \%$ студентів), США (22\%), Нідерланди (20\%), Іспанію, Німеччину та Швецію (по 18\%), Норвегію (16\%), Францію (12\%). Також респондентами були названі Данія, Італія, Росія, Фінляндія, Австрія, Японія, Австралія, Ірландія, Китай, Латвія, Литва, Португалія та Угорщина.

Основними причинами вибору освіти за кордоном респонденти визначили: отримання досвіду проживання у новому суспільстві (94\% респондентів), покращення знання іноземної мови (86\%), отримання освіти вищої якості (76\%) та можливість заробити гроші $(76 \%)$.

Пріоритетними країнами 3 позиції працевлаштування в майбутньому для респондентів $є$ США (назвали 40\% респондентів), Австралія та
Іспанія (по 24\%), Німеччина (16\%), Норвегія та Італія (по 14\%), Велика Британія (12\%), Франція та Швеція (по 10\%). Також були названі Фінляндія, Португалія, Нідерланди та Ісландія (по 6\%), Австрія, Японія, Нова Зеландія і Таїланд (по 4\%), Хорватія, Латвія, Литва, Сінгапур, Канада, Мальта, Шотландія, Мексика, Данія, Ірландія, Росія (по 2\%). В цілому більшість студентів обрали різні країни СС.

На питання «що обумовило такий Ваш вибір?» (студенти мали можливість вказати до трьох аргументів), 82\% респондентів назвали знання мови, $76 \%$ - географічну близькість, $62 \%$ - високий рівень доходів, 28\% - наявність друзів/родичів/знайомих, 14\% - можливість отримати дозвіл на проживання. 49\% респондентів погодилася б на нелегальну роботу за кордоном, 74\% готові працювати за кордоном до одного року з метою заробити гроші з подальшим поверненням до Естонії.

Близько 60\% респондентів відповіли, що планують навчатись або працювати у найближчому майбутньому за кордоном. Головними push-

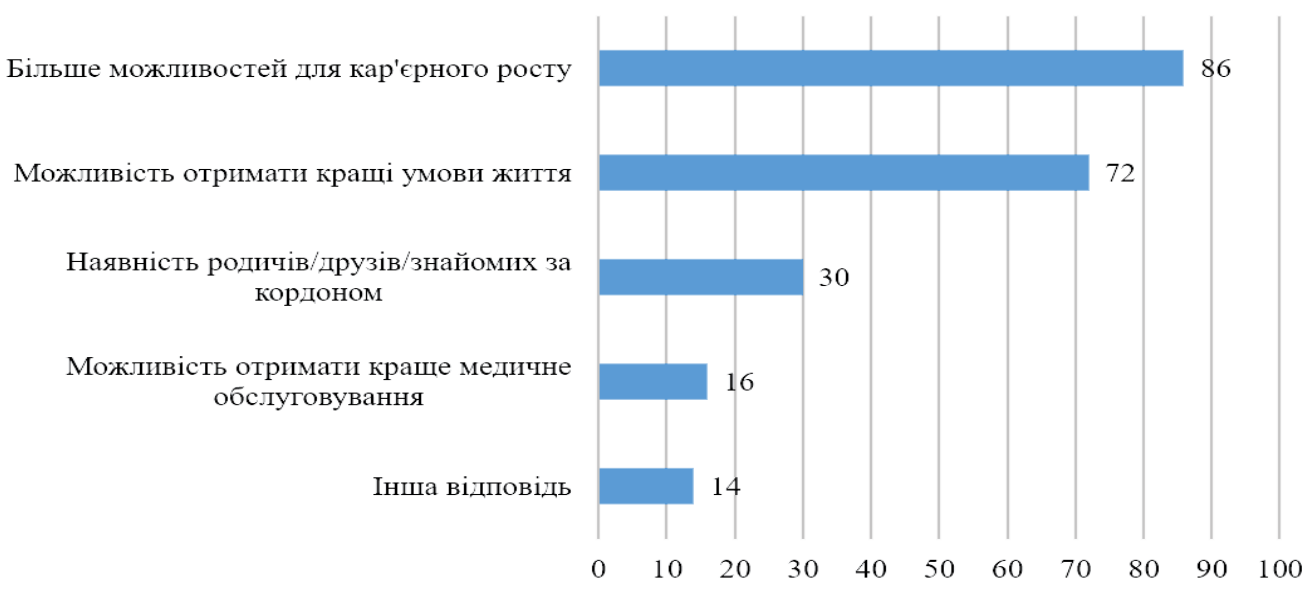

Рис. 5. Розподіл відповідей респондентів на питання «що може спонукати Вас поїхати за кордон на постійне місце проживання?»

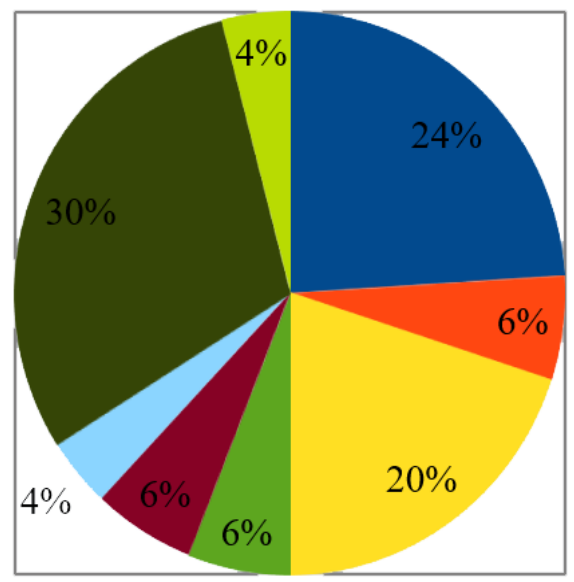

продовжити навчання (здобути ще одну освіту) в Естонії

продовжити навчання (отримати іншу освіту) за кордоном

працювати за спеціальністю в Таллінні

працювати за спеціальністю в іншому місті в Естонії

шрацювати за спеціальністю за кордоном

шрацювати за іншою спеціальністю

चе не визначився(лась)

ш інша відповідь

Рис. 6. Розподіл відповідей респондентів щодо планів після закінчення університету 
факторами можливого виїзду за кордон респонденти назвали низький рівень заробітної плати (36\%), неможливість працювати за обраною спеціальністю (18\%), відсутність можливостей для професійної самореалізації (12\%). Основними причинами, які стримують респондентів від виїзду за кордон, $€$ наявність родичів та друзів, а також задоволення рівнем життя в Естонії.

Основними факторами, які спонукають студентів виїхати за кордон на постійне місце проживання, були названі такі (студентам пропонувалось назвати кілька факторів): більше можливостей для кар'єрного росту $(86 \%)$, можливість мати кращі умови життя (72\%), наявність родичів/друзів/знайомих за кордоном (30\%) (рис. 5).

Відповіді респондентів на питання «що спонукало б Вас поїхати за кордон на постійне місце проживання?» були проаналізовані у взаємозв'язку із освітою їх батьків та рівнем володіння іноземною мовою. В цілому, рівень освіти батьків не вплинув на диференціацію відповідей респондентів. В той же час, було виявлено зв'язок між рівнем освіти батьків та рівнем володіння іноземною мовою опитаних студентів. Так, респонденти, батьки яких не мають ні професійної, ні вищої освіти, мають вищий рівень володіння іноземною мовою. Зокрема, 62,5\% 3 них вказали про рівень $\mathrm{C} 1 / \mathrm{C} 2$ володіння англійською мовою при середньому показнику володіння мовою на такому рівні 30,9\%. Респонденти, батьки яких закінчили коледжі, мають найнижчий рівень володіння англійською мовою (лише 15,4\% вказали, що володіють на рівні $\mathrm{C} 1 / \mathrm{C} 2$ ). Така відмінність у бажанні оволодіти іноземною (зокрема, англійською) мовою частково пояснюється розумінням респондентів можливостей i перспектив трудової діяльності 3 огляду на життєвий досвід своїх батьків.

Порівняння відповідей респондентів, що брали участь в освітніх програмах та програмах 3 працевлаштування за кордоном з відповідями решти респондентів проводилось за такими питаннями: «чи плануєте Ви навчатись або працювати за кордоном у найближчому майбутньому?» та «що спонукало б Вас поїхати за кордон на постійне місце проживання?». Отримані результати є такими: $73,3 \%$ респондентів, що працювали або навчались за кордоном, на запитання «чи плануєте Ви навчатись або працювати за кордоном у найближчому майбутньому?» відповіли ствердно, натомість серед решти ця частка $\epsilon$ меншою і становить 56,8\%. Стосовно питання про причини, які спонукають до виїзду за кордон, то відповіді порівнюваних груп респондентів суттєво не відрізняються.

3. Міграційний потенціал студентської молоді.

Всі респонденти в різні періоди свого життя побували за кордоном. 98,0\% опитаних були у країнах Центральної та Східної Європи, 89,8\% відвідували країни Західної Європи, по 36,7\% - країни Азії та Африки, 18,4\% респондентів побували в країнах Англо-Америки, 8,2\% - в країнах Латинської Америки, 2,0\% - в Австралії. Ідентичними $\epsilon$ відсотки відвідування вище перерахованих країн різних регіонів світу і батьками респондентів.
Вищим є відсоток відвідування батьками лише країн Африки (50,0\% проти 36,7\%) та Англо-Америки (27,1\% проти $18,4 \%)$.

Як мету поїздок за кордон (пропонувалось назвати 1-3 варіанти) 100\% респондентів вказали туризм, 46\% виїжджали для участі у спортивних змаганнях, 40\% - для відвідування родичів та друзів, 34\% зазначили також навчання або участь у наукових заходах, 30\% - участь у культурних заходах, 16\% їздили на роботу.

Всі респонденти зазначили, що володіють на високому рівні англійською мовою (64\% на рівні $\mathrm{C} 1 / \mathrm{C} 2$ та $36 \%$ на рівні $\mathrm{B} 1 / \mathrm{B} 2)$. 64\% на початковому рівні володіють російською мовою. По 24\% респондентів мають початковий рівень володіння німецькою, французькою та фінською мовами.

Респондентам було задане питання про плани після закінчення навчання в університеті. Відповіді продемонстрували, що майже третина опитаної молоді ще не визначилась 3 планами (рис. 6). 24\% опитаних планують продовжити навчання (здобути ще одну освіту) в Естонії, 20\% - працювати за спеціальністю в Таллінні, по 6\% - працювати за спеціальністю в іншому місті в Естонії або за кордоном, 4\% - працювати за іншою спеціальністю.

Щодо визначення сфер та типів зайнятості, молоді люди керуються модними тенденціями у суспільстві. Зокрема, 48\% респондентів планують після закінчення університету мати власний бізнес, $26 \%$ - займатись фрілансом, 14\% - працювати в офісі, $6 \%$ - на державній службі.

Отже, міграційний потенціал опитаної студентської молоді $є$ досить високим. При цьому $50 \%$ молодих людей обрали для продовження навчання чи роботи країну свого проживання, а $30 \%$ ще не визначились зі своїм майбутнім.

Висновки 3 проведеного дослідження. Аналіз ситуації на молодіжному ринку праці показав, що входження Естонії до ЄС мало позитивний ефект як для ринку праці молоді, так і для економіки в цілому. Стабілізація та покращення соціально-економічної ситуації в Естонії стало однією з головних причин збільшення міграційного притоку молоді 3 інших країн ЄC, Росії та з України. Завдяки збільшенню притоку мігрантів останні п'ять років Естонія стала країною $з$ позитивним сальдо міграції, що частково вирішило проблему відтоку естонської молоді до сусідніх більш розвинених країн СС.

Аналіз результатів опитування студентської молоді виявив, що факторами виштовхування студентської молоді Естонії за кордон $\epsilon$, насамперед, економічні (рівень оплати праці, умови життя та праці) та фактор особистого професійного зростання. Міграційні прагнення опитаної студентської молоді $\epsilon$ достатньо високими. Пріоритетними в сенсі освіти та працевлаштування для студентської молоді є країни ЄС, США та Австралія, тобто країни з позитивним іміджем для імміграції, високою оплатою праці, сприятливими умовами для трудової діяльності сезонних працівників та потребою у трудових мігрантах i, 
насамперед, молоді. Додатковим фактором є знання англійської мови, що полегшує період адаптації в приймаючих країнах.

Поширеним видом міграції молоді в Естонії $є$ циркулярна міграція. Також можна вести мову про ланцюгову міграцію, тобто міграцію за сприяння родичів, знайомих, що вже виїхали і можуть допомогти/допомагають фінансово та інформаційно.

Одним 3 визначальних чинників імміграції молоді з України до Естонії є поширення російської мови, що значно полегшує адаптацію та інтеграцію мігрантів, вища заробітна плата та потреба Естонії у працівниках з України, які вирізняються високою працездатністю і задіяні у різних галузях економіки, в т. ч. і непрестижних для місцевих жителів.

Дослідження молодіжного ринку праці та міграційних настроїв студентської молоді Естонії важливе 3 точки зору порівняння 3 проблемами молодіжного безробіття в Україні. Це важливо для розуміння міграційної поведінки української студентської молоді в контексті національної безпеки, проведення соціально-економічних реформ та міграційної політики держави. Саме на цих аспектах будуть сконцентровані подальші дослідження молодіжного ринку праці в Україні та моделей міграційної поведінки студентської молоді.

\section{References:}

1. American Institute of Public Opinion. (2020). Potential Net Migration Index. Retrieved from: https://news. gallup.com/migration/interactive.aspx.

2. Anniste, K. (2014). East-West migration in Europe: The case of Estonia after regaining independence. Dissertationes geographicae Universitatis Tartuensis, 57. 20 p.

3. Anniste, K., Tammaru, T., Pungas, E., \& Paas, T. (2012). Emigration after EU enlargement: Was there a brain drain effect in the case of Estonia? 20 p.University of Tartu Faculty of Economics and Business Administration Working Paper, 87-2012. Available at: https://ssrn.com/abstract=2070036

4. Brettell, C., \& Hollifield, J. F. (eds.). (2014). Migration theory: talking across disciplines. Routledge.

5. Brixiova, Z., \& Egert, B. (2012). Labour Market Reforms and Outcomes in Estonia. Comparative Economic Studies, 54, 103- 120.

6. Eamets, R. (2013). Labour market and labour market policies during great recession: the case of Estonia. IZA Journal of European Labor Studies, 2, 1-25.

7. Dubych, K. V. (2017). The current global trends and Ukraine's realities in youth unemployment. Bulletin of the NAPA under the President of Ukraine (Series “Public Administration"), 3, 87-94. [Дубич К.В. Сучасні світові тенденції та українські реалії молодіжного безробіття. Вісник НАДУ при Президентові України. Серія «Державне управління». 2017. Вип. 3. С. 87-94].

8. Grzymala-Kazłowska, A., \& Brzozowska, A. (2017). From drifting to anchoring. Capturing the experience of Ukrainian migrants in Poland. Central and Eastern European Migration Review, 6(2), 103-122.

9. Lindemann, K. (2014). The effects of ethnicity, language skills, and spatial segregation on labour market entry success in Estonia. European Sociological Review, 30(1), 35-48.

10. Lindemann, K., \& Kogan, I. (2013). The role of language resources in labour market entry: comparing Estonia and Ukraine. Journal of Ethnic and Migration Studies, 39(1), 105-123.

11. Maidanik, I. P. (2010). Ukrainian youth in the labor markets of foreign countries. Kyiv: Ptoukha Institute for Demography and Social Studies of the National Academy of Sciences of Ukraine [Майданік І.П. Українська молодь на ринках праці зарубіжних держав. Київ: Інститут демографії та соціальних досліджень імені М. В. Птухи НАН України, 2010. 176 с.].

12. Masso, J., Eamets, R., \& Mõtsmees, P. (2014). Temporary migrants and occupational mobility: evidence from the case of Estonia. International Journal of Manpower, 35(6), 753-775.

13. Masso, J., Kureková, L.M., Tverdostup, M., \& Žilinčíková, Z. (2018). What are the employment prospects for young Estonian and Slovak return migrants? In O’Reilly, J., Leschke, J., Ortlieb, R., Seeleib-Kaiser, M., \& Villa, P. (eds.). Youth Labor in Transition: Inequalities, Mobility, and Policies in Europe. Oxford University Press.

14. Mezentsev, K., \& Mezentseva, N. (2018). Migratory behaviour of student youth: a path to a career abroad or a situational opportunity for self-realization? In Region-2018: search for optimal development strategy (pp. 33-37). Kharkiv: V. N. Karazin Kharkiv National University [Мезенцев К.В., Мезенцева Н.I. Міграційна поведінка студентської молоді: шлях до кар'єри за кордоном чи ситуативна можливість самореалізації? Регіон-2018: пошук стратегї̈ оптимального розвитку. Харків: Харківський національний університет імені В.Н. Каразіна, 2018. С. 33-37].

15. Mezentsev, K., Mezentseva, N., Mostova, I., \& Saichuk V. (2014). Geography of labour: modern concepts and regional labour markets. Kyiv: Kyiv University Press. [Мезенцев К. В., Мезенцева Н. І., Мостова І. О. Сайчук В. С. Географія праці: сучасні концепти та ринки праці регіонів. Київ: ВПЦ «Київський університет». 210 с.].

16. Nugin, R. (2014). "I think that they should go. Let them see something". The context of rural youth's outmigration in post-socialist Estonia. Journal of Rural Studies, 34, 51-64.

17. Paliskova, M. (2014). Youth Unemployment - Problem of the European Labor Market. In8th International Days of Statistics and Economics (pp. 1083-1093). Prague.

18. Sippola, M. (2014). Labour migration in the case of Estonia and Kyrgyzstan: disillusionment with lack of opportunity in the homeland. The Journal of Social Policy Studies, 12(4),613-624.

19. Niemets, L., \& Mezentsev, K. (eds.). (2019). Social Geography. Kyiv: Phoenix. [Соціальна географія /за ред. Л.Нємець, К.Мезенцева. Київ: Фенікс, 2019. 304 с.].

20. Statistics Estonia (2020). Retrieved from: https://www.stat.ee.

21. Tverdostup, M., \& Masso, J. (2016). The labour market performance of young return migrants after the crisis in CEE countries: the case of Estonia. Baltic Journal of Economics, 16(2), 192-220. 